\title{
Controlled growth of $\beta-\mathrm{Na}_{0.24} \mathrm{~V}_{2} \mathrm{O}_{5}$ nanowire thin films
}

\author{
Jhih-Syuan Ke $\cdot$ Ming-Cheng Wu • \\ Sheng-Feng Weng $\cdot$ Chi-Shen Lee
}

Received: 18 March 2012/ Accepted: 28 August 2012

(C) Springer Science+Business Media B.V. 2012

\begin{abstract}
A method to prepare well-aligned $\beta-\mathrm{Na}_{0.24} \mathrm{~V}_{2} \mathrm{O}_{5}$ nanowires (NWs) involves the deposition of a vanadium oxide complex onto a substrate via gaseous transport, followed by a reaction between the complex and a sodium cation $\left(\mathrm{Na}^{+}\right)$precursor coated on the substrate. Techniques to investigate the composition, crystallinity, and morphology of products as prepared include ICP-AES, X-ray powder diffraction (PXRD), SEM/transmission electron microscope (TEM), and XPS. PXRD patterns and images from a TEM confirm the single-crystalline nature of $\beta-\mathrm{Na}_{0.24} \mathrm{~V}_{2} \mathrm{O}_{5}$ NWs, which grow along direction $\left[\begin{array}{lll}1 & 0 & 0\end{array}\right]$. Factors affecting the amount of deposited material and morphology were tested. On varying the reaction conditions, the length of the $\beta-\mathrm{Na}_{0.24} \mathrm{~V}_{2} \mathrm{O}_{5}$ wires is controlled in a range of 5-25 $\mu \mathrm{m}$. A mechanism of formation is proposed. According to measurements of field emission, the turn-on field is $7.8 \mathrm{~V} / \mu \mathrm{m}$, and the maximum emission current density of $4.66 \mathrm{~mA} / \mathrm{cm}^{2}$ occurs at field $11 \mathrm{~V} / \mu \mathrm{m}$. This method is applicable to grow other tertiary metal oxide nanostructures on glass substrate.
\end{abstract}

Keywords $\quad \beta-\mathrm{Na}_{0.24} \mathrm{~V}_{2} \mathrm{O}_{5} \cdot$ Nanowire $\cdot$ Film . Morphology control

J.-S. Ke · M.-C. Wu · S.-F. Weng · C.-S. Lee ( $\square)$ Department of Applied Chemistry, National Chiao Tung University, 1001 University Road, Hsinchu 30010, Taiwan

e-mail: chishen@mail.nctu.edu.tw

\section{Introduction}

One-dimensional (1D) nanomaterials are of great technological importance. In particular, metal oxide with 1D nanostructures in belt, rod, wire, and nanotube forms have been developed for their specific physical properties and prospective applications as catalysts and in photoelectronic, sensor, cell, and thermoelectric devices (Jiang et al. 2006; 2011; Wei and Natelson 2011; Zhai et al. 2011; Ramgir et al. 2010; Wang 2008; Liu et al. 2007; 2008; Sanmathi et al. 2010; Li et al. 2007; 2009, 2010; Fan et al. 2009; Zhang et al. 2006; Wang and Cao 2006, 2007; Nayak et al. 2008; Wang et al. 2008, 2010; Santangelo et al. 2010). Of these materials, the 1D nanostructure of vanadium oxide and its derivative compounds have diverse practical applications in chemical sensors (Isabelle et al. 2005; Liu et al. 2005; Grigorieva et al. 2010; Bakhteeva et al. 2010), electrochromic devices (Xiong et al. 2008b), ultrafast optical switchers (Ji et al. 2010), and electrodes for rechargeable lithium batteries (Jiao et al. 2006) for their unique structural features. Various protocols to synthesize the 1D nanostructure of vanadium oxide, vanadium bronzes, and intercalated vanadate have been published (Zhou et al. 2005; An et al. 2010; Perlstein 1968; Galy 1992; Xiong et al. 2008a; Velazquez and Banerjee 2009; Velazquez et al. 2009).

As a member of the vanadium oxide derivative compounds, $\beta-\mathrm{Na}_{x} \mathrm{~V}_{2} \mathrm{O}_{5}(x=0.23-0.41)$ has attracted much interest for its novel physical, magnetic, and superconductive properties under critical conditions 
(Yamada and Ueda 1999; Itoh et al. 2001). $\beta-\mathrm{Na}_{x} \mathrm{~V}_{2} \mathrm{O}_{5}$ possesses a rigid $3 \mathrm{D}$ network that differs from the layertype structure of $\mathrm{V}_{2} \mathrm{O}_{5} . \mathrm{Na}^{+}$ions are located inside the tunnels of the $\mathrm{V}-\mathrm{O}$ frame, resulting in mixed-valence states $\mathrm{V}^{5+}\left(\mathrm{d}^{0}\right)$ and $\mathrm{V}^{4+}\left(\mathrm{d}^{1}\right)$. This particular feature is expected to improve the properties of ion and electronic transport, as well as charge storage for applications in super capacitor or cathode material in a lithium battery (Liu et al. 2009; Khoo et al. 2010; Xu et al. 2011). $\beta-\mathrm{Na}_{x} \mathrm{~V}_{2} \mathrm{O}_{5} 1 \mathrm{D}$ nanostructures have been synthesized by chemical vapor deposition (CVD) and hydrothermal routes (Zhou et al. 2005; Liu et al. 2009; Khoo et al. 2010; Sahana and Shivashankar 2003). Nanowires (NWs) of $\mathrm{Na}_{1+x} \mathrm{~V}_{3} \mathrm{O}_{8}$ and $\beta-\mathrm{Na}_{x} \mathrm{~V}_{2} \mathrm{O}_{5}$ have been grown on glass substrates (Sahana and Shivashankar 2003; Xu et al. 2005); the source of $\mathrm{Na}^{+}$ions was the substrate from which they diffused into the vanadium oxide precursor.

We developed a facile method to control the growth of nearly aligned $\mathrm{MoO}_{3}$ and $\mathrm{V}_{2} \mathrm{O}_{5}$ NWs on various substrates (Wu and Lee 2009a, b). The formation of $\mathrm{V}_{2} \mathrm{O}_{5} \mathrm{NWs}$ was affected by the polyvanadate species, $\mathrm{VO}_{x}$, and the reaction temperature; this synthesis might allow for the growth of new metal oxides with a 1D nanostructure. We assumed that the polyvanadate species was highly active and tended to react with a target species on the surface during deposition. On the basis of this concept, we deposited bronze vanadium oxide $\beta-\mathrm{Na}_{0.24} \mathrm{~V}_{2} \mathrm{O}_{5}$ NWs as a ternary phase on a substrate via a procedure that was modified with an additional treatment of the surface of the substrate. The source of the $\mathrm{Na}^{+}$was sodium silicate that was first coated on the substrate; the amount of precursor was carefully controlled. Several parameters, including reaction temperature and the concentrations of reactants, were found to play important roles in controlling the morphology of the final products. From measurements of the field emission, the results showed small actuation voltages and a large current density of $\beta-\mathrm{Na}_{0.24} \mathrm{~V}_{2} \mathrm{O}_{5} \mathrm{NW}$ arrays; these properties would be useful in optoelectronic nanodevices

\section{Experiments}

Synthesis

Thin films of $\beta-\mathrm{Na}_{0.24} \mathrm{~V}_{2} \mathrm{O}_{5} \mathrm{NW}$ were grown on a substrate in a two-step synthesis comprising a substrate treatment and thermal evaporation.

\section{Substrate treatment}

Sodium metasilicate solutions $\left(\mathrm{Na}^{+}\right.$solution) were prepared by dissolving sodium metasilicate $\left(\mathrm{Na}_{2} \mathrm{SiO}_{3} \cdot 9 \mathrm{H}_{2} \mathrm{O}\right)$ in deionized water with concentrations ranging from 0.0125 to $0.05 \mathrm{M}$. Before the coating treatment, a sodium-free glass substrate $(2 \times 1 \mathrm{~cm})$ was first cleaned with ethanol and deionized water; the solution $(0.2 \mathrm{~mL})$ as prepared was then dropped onto the substrate, followed by drying overnight at $40{ }^{\circ} \mathrm{C}$ to form a thin film of sodium metasilicate salt on the glass.

\section{Thermal evaporation}

To prepare the solution for each precursor, fine $\mathrm{V}_{2} \mathrm{O}_{5}$ powder $(0.1 \mathrm{~g}, 0.55 \mathrm{mmol})$ and $\mathrm{NH}_{2} \mathrm{OH} \cdot \mathrm{HCl}_{(\mathrm{aq})}(3 \mathrm{M}$, $2 \mathrm{~mL}$ ) were mixed thoroughly in a glass vial with magnetic stirrer at $50{ }^{\circ} \mathrm{C}$. The concentration of the precursor solution ranged from 0.15 to $0.45 \mathrm{M}$ with $\mathrm{V}_{2} \mathrm{O}_{5}$ and $\mathrm{NH}_{2} \mathrm{OH} \cdot \mathrm{HCl}$ in a fixed ratio. The mixture eventually turned from orange to blue, indicating the reduction of $\mathrm{V}_{2} \mathrm{O}_{5}$ to species with low oxidation state of vanadium. A glass substrate as prepared was then placed on the top of the vial, and this installation was transferred into a furnace. The temperature was raised to $300-400{ }^{\circ} \mathrm{C}$ at a constant rate of $100{ }^{\circ} \mathrm{C} / \mathrm{h}$ and held there for $1 \mathrm{~h}$. Well-aligned $\beta-\mathrm{Na}_{0.24} \mathrm{~V}_{2} \mathrm{O}_{5}$ NWs were then found on the lower side of the glass substrate.

\section{Characterization}

The thin film products as prepared were characterized with several analytical techniques. The purity and crystallinity of the as-prepared products was examined by powder X-ray diffraction (XRD, Bruker AXS D8 Advance, Leipzig Germany, operated at $40 \mathrm{kV}$ and $40 \mathrm{~mA}$ with $\mathrm{Cu}-\mathrm{K} \alpha$ radiation at $\lambda=1.54060 \AA$ ). Cell parameters were refined with the program CELREF (B. Laugier). The chemical composition of the $\beta-\mathrm{Na}_{0.24} \mathrm{~V}_{2} \mathrm{O}_{5}$ NWs was determined with an inductively coupled plasma-atomic emission spectrometer (ICP-AES, Jarrell-AshICAP 9000). The crystal morphology and dimensions of the NWs were determined from the micrograph analyses with a scanning electron microscope (SEM, Hitachi, S-4700I, operated at $15 \mathrm{kV}$ ) and a transmission electron microscope (TEM, JEOL, JEM-3000F, operated at $200 \mathrm{kV}$ ). To prepare the sample for the TEM experiment, we 
scraped the $\beta-\mathrm{Na}_{0.24} \mathrm{~V}_{2} \mathrm{O}_{5}$ NWs from the glass and dispersed in ethanol by ultrasonic treatment for $5 \mathrm{~min}$. The resulting solution was then dropped onto a copper grid (carbon-coated, 100 mesh), and dried in air to spread the NWs on the carbon film. For the analysis with X-ray photoelectron spectra (XPS, PHI Quantera SXM spectrometer), the binding energy was calibrated with the C-1s line at $284.4 \mathrm{eV}$. Diffuse reflectance spectra were measured near $25^{\circ} \mathrm{C}$ with a UV-Visible spectrophotometer (Hitachi/U-3010) and an integrating sphere over a range $400-800 \mathrm{~nm}$. To measure the field emission, we placed the $\beta-\mathrm{Na}_{0.24} \mathrm{~V}_{2} \mathrm{O}_{5}$ thin films in a vacuum chamber (pressure less than $5 \times 10^{-6} \mathrm{~Pa}$, near $295 \mathrm{~K}$ ). The distance from the sample to the electrode was adjusted to $100 \mu \mathrm{m}$; the current-voltage characteristics were recorded with a high-voltage source meter (Keithley 2410).

\section{Results and discussion}

\section{Synthesis and characterization}

The crystal structure, morphology, and composition of the $\mathrm{Na}_{x} \mathrm{~V}_{2} \mathrm{O}_{5} \mathrm{NWs}$ were characterized by powder XRD, scanning electron microscopy (SEM), TEM, inductively coupled plasma-atomic emission spectrometer (ICP-AES), and X-ray photoelectron spectroscopy (XPS). Figure 1 shows XRD patterns of the products, synthesized at various temperatures, deposited on a glass substrate. The patterns were indexed on the basis of a monoclinic unit cell with refined lattice parameters $a=15.40 \quad$ (3) $\AA, \quad b=3.612 \quad$ (3) $\AA$, $c=10.05$ (3) $\AA$, and $\beta=109.5^{\circ}(2)$, which were near the XRD patterns calculated for $\mathrm{Na}_{0.76} \mathrm{~V}_{6} \mathrm{O}_{15}$ (JCPDS number: 75-1653, space group: $C 2 / m$, No. 12). As shown in Fig. 1, a sample synthesized at a temperature of $300{ }^{\circ} \mathrm{C}$ exhibited a broad XRD signal. The reaction temperature also affected the intensity of the Bragg lines. For a sample prepared at $400{ }^{\circ} \mathrm{C}$, a sharp XRD signal with a large ratio of signal to noise was observed. The strongest Bragg feature set was located at $\left(\begin{array}{lll}1 & 1 & -1\end{array}\right)$, whereas the samples prepared at a temperature at 300 and $350{ }^{\circ} \mathrm{C}$ exhibited a maximum diffractions of $(00-1)$ and $(11-1)$, respectively. The results indicated that the as-deposited NWs synthesized at $400{ }^{\circ} \mathrm{C}$ exhibited preferential geometrical orientation with a $\left(\begin{array}{lll}1 & 1 & -1\end{array}\right)$ facet. No obvious preferential orientation was observed for samples

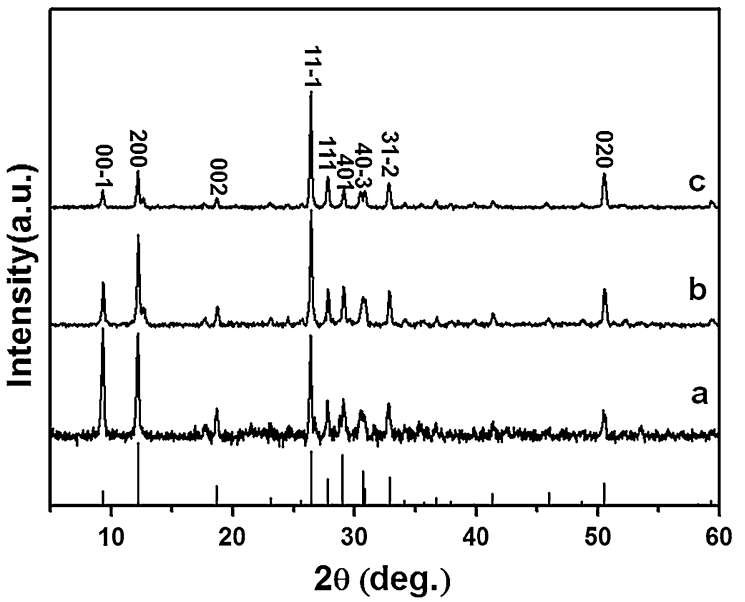

Fig. 1 Calculated XRD pattern and XRD profiles of a typical product synthesized at temperatures $(a) 300{ }^{\circ} \mathrm{C},(b) 350{ }^{\circ} \mathrm{C}$, and (c) $400{ }^{\circ} \mathrm{C}$

synthesized at a lower temperature. According to these results, we speculated that the NWs observed at $T<400{ }^{\circ} \mathrm{C}$ were randomly oriented on the substrate without preferential orientation. This assumption is demonstrated by a cross-sectional view of SEM images in a subsequent section that shows pseudoaligned single crystal NWs. The chemical composition of a typical product, examined with ICP-AES, showed an atomic ratio of $\mathrm{Na} / \mathrm{V} \sim 0.12$. Combination with the XRD results indicated that the NWs deposited on the substrate via thermal evaporation consisted of $\beta$-phase $\mathrm{Na}_{0.24} \mathrm{~V}_{2} \mathrm{O}_{5}$.

The size and morphology of $\beta-\mathrm{Na}_{0.24} \mathrm{~V}_{2} \mathrm{O}_{5}$ NWs synthesized at $400{ }^{\circ} \mathrm{C}$ were examined with SEM and TEM, as shown in Fig. 2. The $\beta-\mathrm{Na}_{0.24} \mathrm{~V}_{2} \mathrm{O}_{5}$ product clearly contained long and uniform NWs of an average length of $35 \mu \mathrm{m}$. The side view, as shown in the inset of Fig. 2a, revealed nearly vertically aligned $\beta-\mathrm{Na}_{0.24} \mathrm{~V}_{2} \mathrm{O}_{5} \mathrm{NWs}$ on the substrate. The TEM image showed a single NW with a width estimated to be 80-100 nm. The electron-diffraction (SAED) pattern of a selected area of a single wire recorded from the $\left[\begin{array}{lll}-1 & 3 & 1\end{array}\right]$ zone axis revealed sharp and clean diffraction spots, indicative of a single-crystalline property (inset of Fig. 2b). A HR-TEM image recorded from the $\left[\begin{array}{lll}-1 & 3 & 1\end{array}\right]$ zone axis indicated lattice fringes at 3.48 and $2.93 \AA$, corresponding, respectively, to crystal planes $\left(\begin{array}{lll}2 & 0 & 2\end{array}\right)$ and $\left(\begin{array}{lll}1 & 1 & -2\end{array}\right)$ of $\beta-\mathrm{Na}_{0.24} \mathrm{~V}_{2} \mathrm{O}_{5}$. The preferred growth direction is perpendicular to the $a$-axis, as deduced from angle 

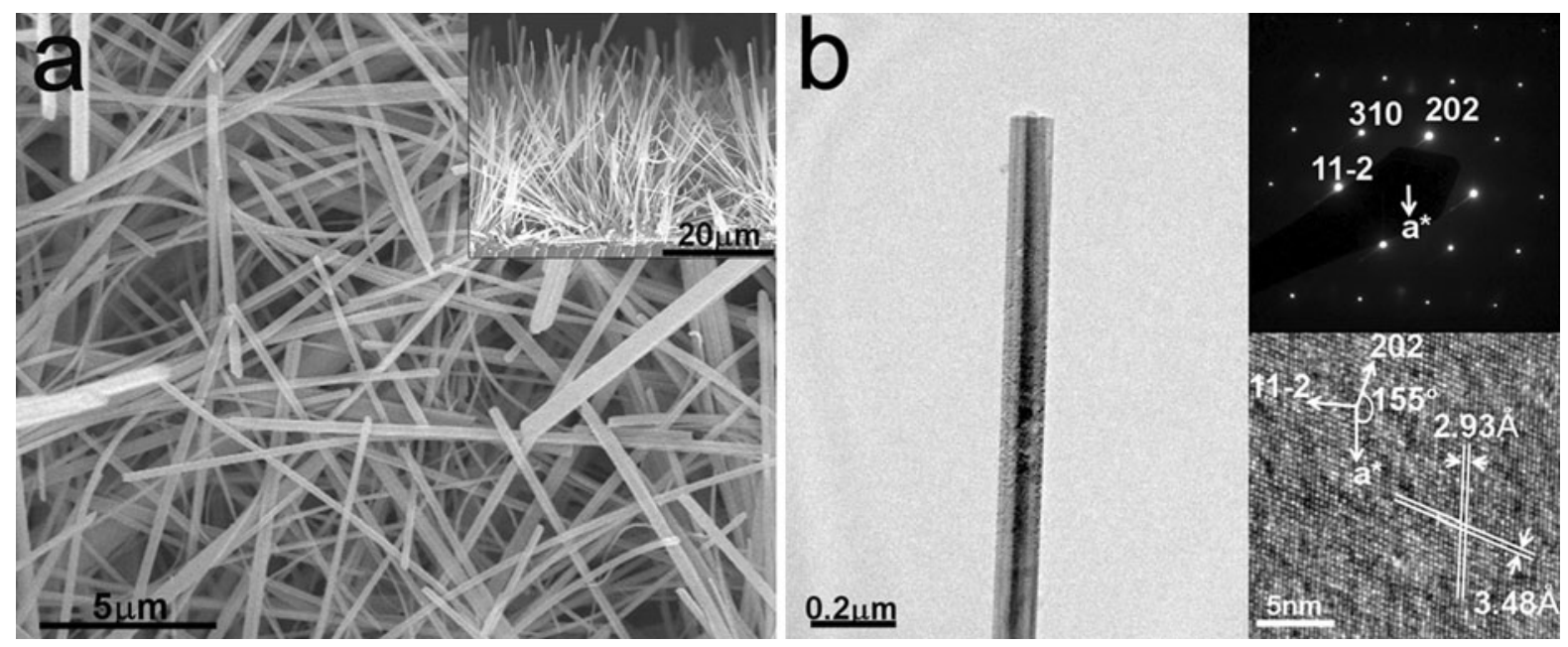

Fig. 2 a Top view SEM image of $\beta-\mathrm{Na}_{0.24} \mathrm{~V}_{2} \mathrm{O}_{5}$ thin film and side view in inset; $\mathbf{b}$ TEM (left), SAED (right top), and HR-TEM (right bottom) images of $\beta$ - $\mathrm{Na}_{0.24} \mathrm{~V}_{2} \mathrm{O}_{5} \mathrm{NWs}$ as obtained. The sample was synthesized at $400{ }^{\circ} \mathrm{C}$

$155^{\circ}$ between the $a$-axis and the normal vector of plane (1 $1-2)$, consistent with preceding work (Liu et al. 2009; Yu and Yu 2007).

XPS provided information about the oxidation states in $\beta-\mathrm{Na}_{0.24} \mathrm{~V}_{2} \mathrm{O}_{5}$ NWs. As shown in Fig. 3a, the spectrum demonstrated the presence of elements $\mathrm{Na}, \mathrm{V}$, and $\mathrm{O}$. The spectrum for the $\mathrm{V}-2 \mathrm{p}$ region (Fig. 3b) showed binding energies (BE) of $\mathrm{V} 2 \mathrm{p}_{3 / 2}$ $(516.15 \mathrm{eV})$ and $\mathrm{V} 2 \mathrm{p}_{1 / 2}(523.71 \mathrm{eV})$. The line in the $\mathrm{V} 2 \mathrm{p}_{3 / 2}$ spectrum exhibited a shoulder, indicative of mixed oxidation states of vanadium ion. According to peak modeling, the $\mathrm{V} 2 \mathrm{p}_{3 / 2}$ spectrum contained two contributions at 516.9 and $515.4 \mathrm{eV}$, corresponding to $\mathrm{V}^{5+}$ and $\mathrm{V}^{4+}$ ions, respectively; similar results have been found for other ternary vanadium oxide bronze compounds. (Liu et al. 2006; Souza et al. 2007).

\section{Effect of reaction conditions}

The effect of reaction temperature, concentration of precursor solution, and amount of sodium metasilicate to coverage density and length of $\beta-\mathrm{Na}_{0.24} \mathrm{~V}_{2} \mathrm{O}_{5} \mathrm{NWs}$ were studied. We tested several conditions to understand the parameters that affected the growth of $\beta-\mathrm{Na}_{0.24} \mathrm{~V}_{2} \mathrm{O}_{5} \mathrm{NWs}$; the results are summarized in Table 1 and Figs. 4, 5, 6. Figure 4a, b, c shows the effect of temperature on $\beta-\mathrm{Na}_{0.24} \mathrm{~V}_{2} \mathrm{O}_{5} \mathrm{NWs}$ at 300 , 350 , and $400{ }^{\circ} \mathrm{C}$, respectively. The average length of NWs increased with increases in the reaction temperature; the film with NWs of the greatest average length was obtained at $400{ }^{\circ} \mathrm{C}$, which was similar to our preceding work on $\mathrm{V}_{2} \mathrm{O}_{5}$ and $\mathrm{MoO}_{3}$ wires $(\mathrm{Wu}$ and Lee 2009a, b). The coverage density of NWs increased with increasing temperature, indicating that the temperature of deposition affected the amount of $\beta-\mathrm{Na}_{0.24} \mathrm{~V}_{2} \mathrm{O}_{5}$ nanocrystals created on the substrate. The space of NW growth became limited when the coverage density of NWs was large, resulting in the growth direction of NWs being nearly perpendicular to the surface, from lack of space for growth along the horizontal orientation. According to powder XRD study, the $\beta-\mathrm{Na}_{0.24} \mathrm{~V}_{2} \mathrm{O}_{5} \mathrm{NWs}$ films showed preferred geometrical orientation along the $\left(\begin{array}{lll}1 & 1 & -1\end{array}\right)$ plane. For a substrate with a small coverage density of NWs, we observed randomly oriented NWs lying on the substrate due to a scattered distribution of NWs that collapsed after the reaction. These results indicated that the length and amount of $\beta-\mathrm{Na}_{0.24} \mathrm{~V}_{2} \mathrm{O}_{5} \mathrm{NWs}$ were controllable through the reaction temperature. The substrates with NWs in a preferred geometrical orientation were observed for samples synthesized at temperatures greater than $350{ }^{\circ} \mathrm{C}$.

The concentrations of the precursor solution and the $\mathrm{Na}$ solution were two additional factors that possibly affected the yield and morphology of the final product. For comparison, we undertook experiments with solutions of the precursor or sodium metasilicate at varied concentrations to synthesize $\beta-\mathrm{Na}_{0.24} \mathrm{~V}_{2} \mathrm{O}_{5}$ 

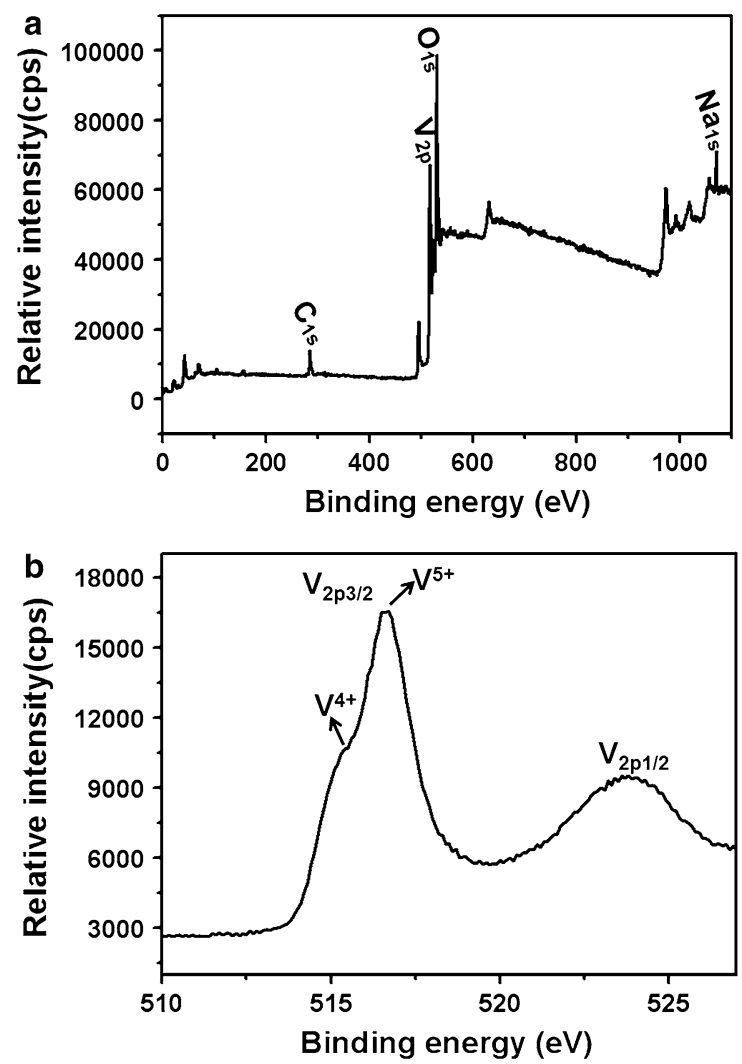

Fig. 3 a Overall XPS spectrum and b highly magnified XPS spectrum for the $\mathrm{V}-2 \mathrm{p}$ region of $\beta-\mathrm{Na}_{0.24} \mathrm{~V}_{2} \mathrm{O}_{5} \mathrm{NWs}$

Table 1 Reaction conditions and morphology properties of $\beta-\mathrm{Na}_{0.24} \mathrm{~V}_{2} \mathrm{O}_{5} \mathrm{NW}$ identified with a SEM

\begin{tabular}{lllll}
\hline $\begin{array}{l}{\left[\mathrm{Na}_{2} \mathrm{SiO}_{3}\right]} \\
(\mathrm{M})\end{array}$ & $\begin{array}{l}{[\text { Precursor }]} \\
(\mathrm{M})\end{array}$ & $\begin{array}{l}\text { Reaction } \\
\text { temperature } \\
\left({ }^{\circ} \mathrm{C}\right)\end{array}$ & $\begin{array}{l}\text { Average length } \\
\text { of NWs }(\mu \mathrm{m})\end{array}$ \\
\hline 1 & 0.05 & 0.3 & 300 & $15(3)$ \\
2 & 0.05 & 0.3 & 350 & $20(4)$ \\
3 & 0.05 & 0.3 & 400 & $26(4)$ \\
4 & 0.05 & 0.45 & 400 & $37(5)$ \\
5 & 0.05 & 0.15 & 400 & $7(2)$ \\
6 & 0.025 & 0.3 & 400 & $15(4)$ \\
7 & 0.0125 & 0.3 & 400 & $13(3)$ \\
\hline
\end{tabular}

NWs while maintaining other synthetic parameters constant. Figures 5 and 6 show NWs in side views on substrates with varied amounts of precursor and sodium metasilicate. In general, the $\mathrm{Na} / \mathrm{V}$ ratio of all reactions yielded $\beta-\mathrm{Na}_{0.24} \mathrm{~V}_{2} \mathrm{O}_{5} \mathrm{NWs}$ in a wire shape that was essentially independent of the reaction temperature. Regarding the effect of the vanadium precursor, the average lengths of $\beta-\mathrm{Na}_{0.24} \mathrm{~V}_{2} \mathrm{O}_{5} \mathrm{NWs}$ were $5.5,23.1$, and $30.5 \mu \mathrm{m}$ for concentrations of $0.15,0.3$, and $0.45 \mathrm{M}$, respectively. As for the reactions with sodium metasilicate in controlled proportions, the average lengths of NWs were 12.2, 15.7 , and $23.1 \mu \mathrm{m}$ for concentrations of $0.0125,0.025$, and $0.05 \mathrm{M}$, respectively. These results indicated that coverage density and length of NWs were dictated by availability of sodium metasilicate and $\mathrm{VO}_{x}$ from precursor; the more precursor provided, the longer the grown $\beta$ - $\mathrm{Na}_{0.24} \mathrm{~V}_{2} \mathrm{O}_{5}$ NWs.

To investigate the mechanism of formation of NWs as prepared, we analyzed their evolution with XRD. The reactions at a fixed temperature of $300{ }^{\circ} \mathrm{C}$ were terminated at reaction durations of 15,30 , and $45 \mathrm{~min}$. The products were collected for XRD measurements, and the results appear in Fig. 7. For the reaction terminated at $15 \mathrm{~min}$, the XRD diffraction features were indexed on the basis of the layered phase $\mathrm{V}_{2} \mathrm{O}_{5} \cdot x \mathrm{H}_{2} \mathrm{O}$, consistent with preceding work (Liu et al. 2005; Dong et al. 2008, 2009; Ard et al. 2011). For the reaction ceased at $30 \mathrm{~min}$, the product contained mixtures of $\mathrm{NaVO}_{3}$ and $\beta-\mathrm{Na}_{0.24} \mathrm{~V}_{2} \mathrm{O}_{5}$, whereas the product obtained from reaction duration of 45 min was identified as $\beta-\mathrm{Na}_{0.24} \mathrm{~V}_{2} \mathrm{O}_{5}$ in a pure single phase.

On the basis of the above experimental observations, a growth model is proposed and illustrated in Scheme 1 . The growth of $\beta-\mathrm{Na}_{0.24} \mathrm{~V}_{2} \mathrm{O}_{5}$ nanostructures proceeds through a gas phase and the process is a catalyst-free method to grow quasi-aligned $\beta-\mathrm{Na}_{0.24} \mathrm{~V}_{2} \mathrm{O}_{5} \mathrm{NWs}$. The mechanism is different from those of vapor-solid (VS) and vapor-liquid-solid (VLS) ones for CVD methods (Wang 2008; Comini et al. 2009; Kolasinski 2006; Dai et al. 2003; Wagner and Ellis 1964). In the initial stage of reaction, polyvanadate species $\left(\mathrm{VO}_{x}\right)$ were created during the thermal evaporation process and deposited on a sodium metasilicate-coated substrate through vapor transport (Wu and Lee 2009b). The polyvanadate species $\left(\mathrm{VO}_{x}\right)$ is considered to comprise mixtures of partially reduced vanadium oxide in amorphous and crystalline phases. Subsequently, the $\mathrm{VO}_{x}$ fragments are delivered to the substrate and $\mathrm{V}_{2} \mathrm{O}_{5} \cdot x \mathrm{H}_{2} \mathrm{O}$ nucleates. The deliveries of the $\mathrm{VO}_{x}$ via vapor phase at a given temperature determine the abundance and length of NWs on the surface. The interaction of $\mathrm{V}_{2} \mathrm{O}_{5} \cdot x \mathrm{H}_{2} \mathrm{O}$ with sodium metasilicate leads to the 

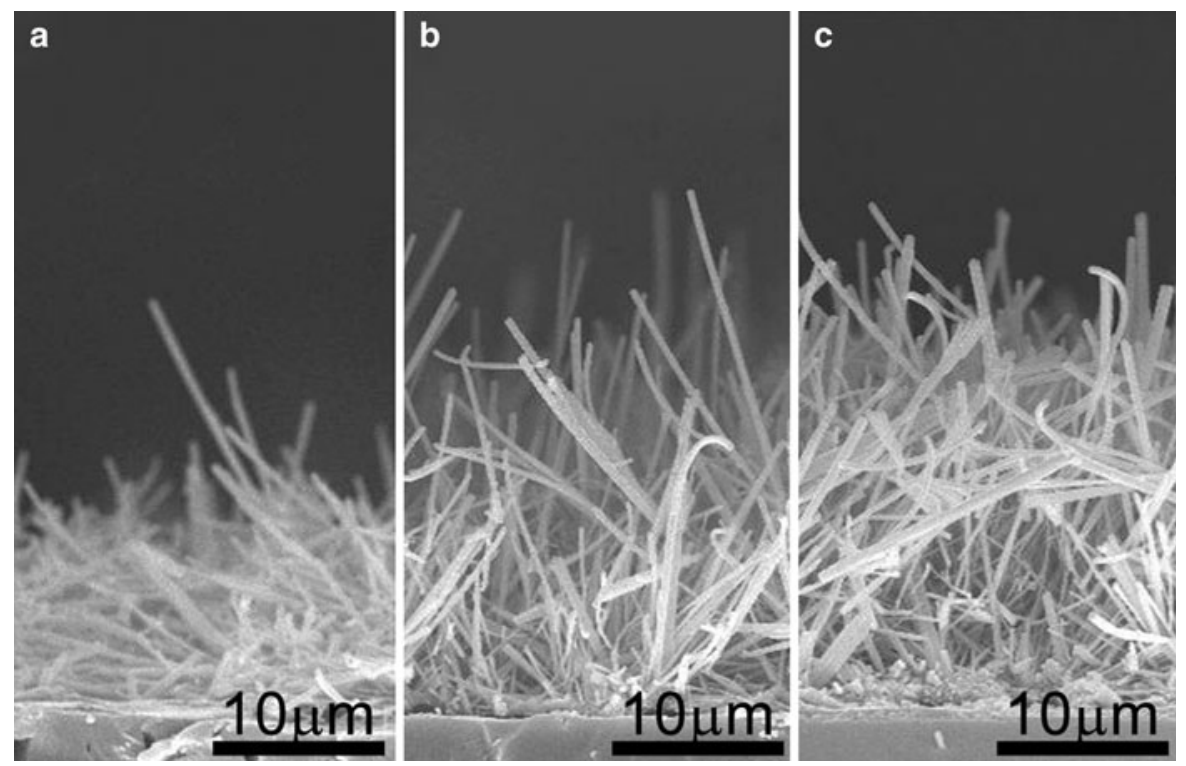

Fig. 4 Side-view images of $\beta-\mathrm{Na}_{0.24} \mathrm{~V}_{2} \mathrm{O}_{5} \mathrm{NW}$ thin films as-prepared, synthesized at $\mathbf{a} 300{ }^{\circ} \mathrm{C}, \mathbf{b} 350{ }^{\circ} \mathrm{C}$, and $\mathbf{c} 400{ }^{\circ} \mathrm{C}$
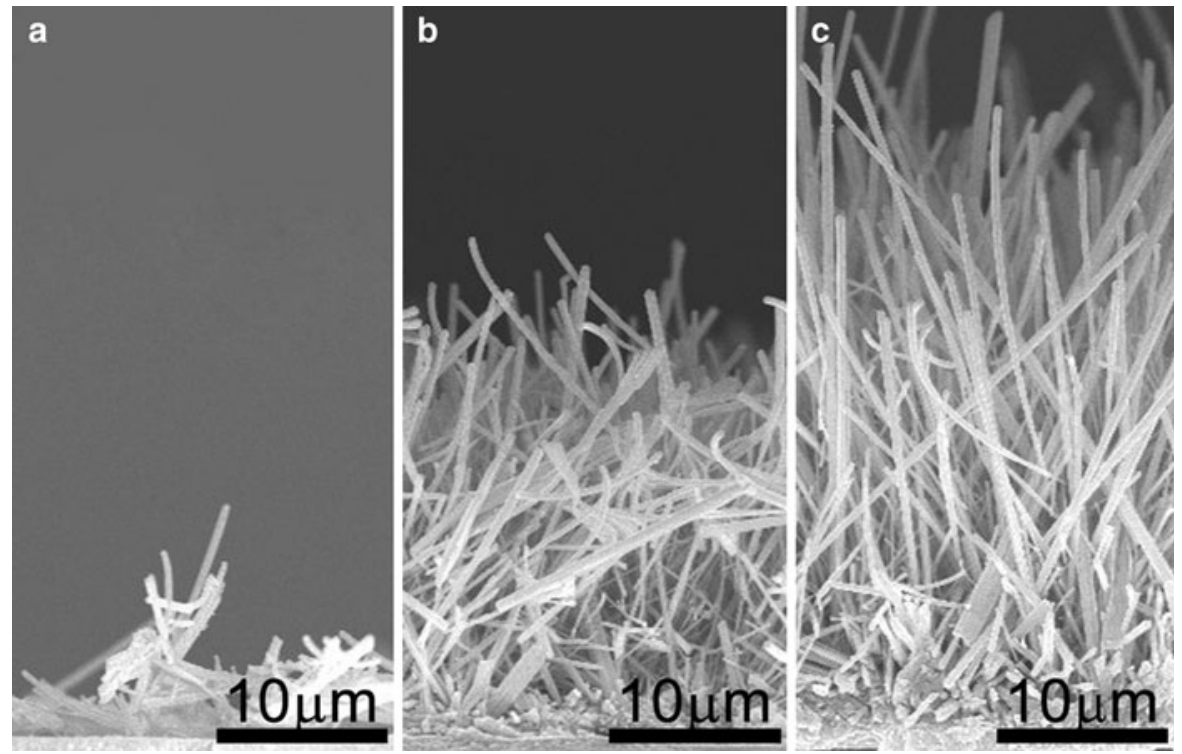

Fig. 5 Side-view images of $\beta-\mathrm{Na}_{0.24} \mathrm{~V}_{2} \mathrm{O}_{5} \mathrm{NW}$ thin films as prepared, synthesized with precursor solution concentrations of a $0.15 \mathrm{M}$, b $0.30 \mathrm{M}$, and c $0.45 \mathrm{M}$

formation of $\mathrm{NaVO}_{3}$ phase. In the next stage, $\mathrm{VO}_{x}$ and $\mathrm{V}_{2} \mathrm{O}_{5} \cdot x \mathrm{H}_{2} \mathrm{O}$ continuously interact with sodium metasilicate to form $\mathrm{NaVO}_{3}$, as soon as sufficient reactants available, nucleation of $\beta-\mathrm{Na}_{0.24} \mathrm{~V}_{2} \mathrm{O}_{5}$ nanoparticle start to form on the surface of glass substrate (Yamada and Ueda 1999).
During the crystal growth process, high coverage density of NWs are packed densely that affect the NWs to grow on surface along the direction nearly perpendicular to the surface of glass substrate, whereas low coverage density of NWs are packed loosely to form randomly oriented NWs. The reaction 

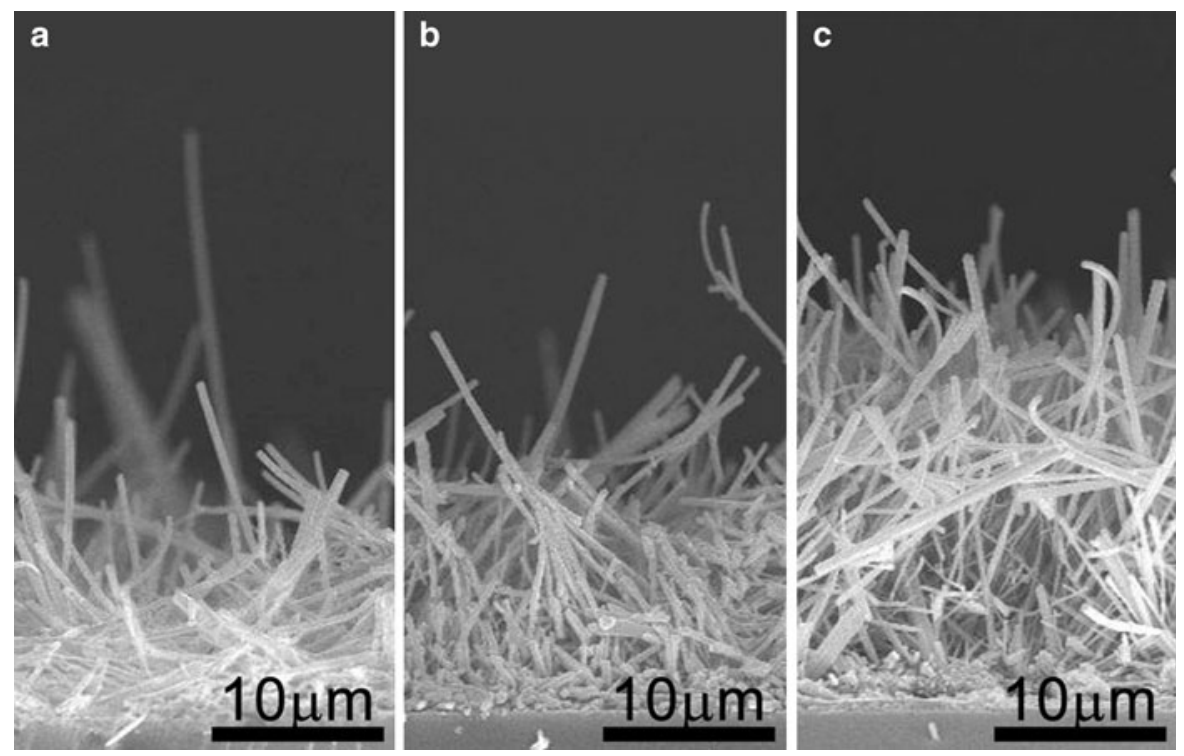

Fig. 6 Side-view images of $\beta-\mathrm{Na}_{0.24} \mathrm{~V}_{2} \mathrm{O}_{5} \mathrm{NW}$ thin films as-prepared, synthesized with $\mathrm{Na}$ solution concentrations of a $0.125 \mathrm{M}$, b $0.025 \mathrm{M}$, and c $0.05 \mathrm{M}$

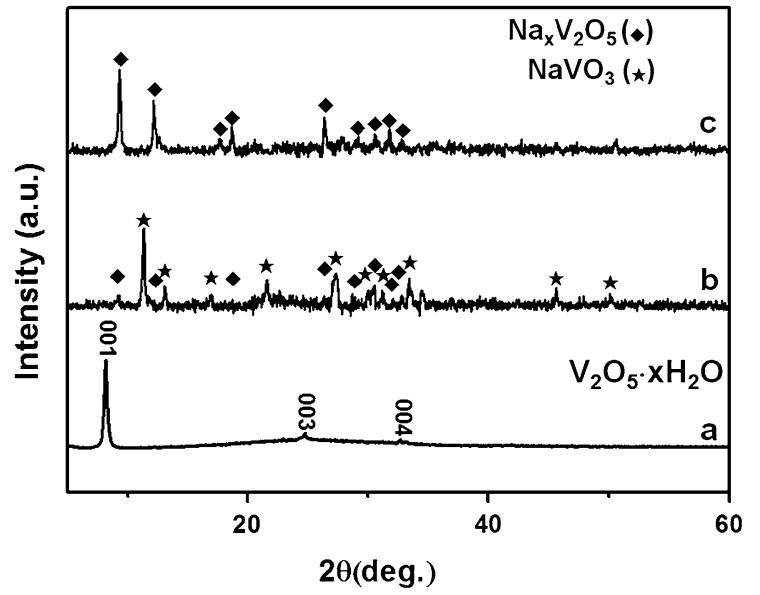

Fig. 7 XRD pattern of a typical intermediate product synthesized during (a) $15 \mathrm{~min},(b) 30 \mathrm{~min}$, and (c) $45 \mathrm{~min}$

for $\mathrm{NaVO}_{3}$ and $\mathrm{V}_{2} \mathrm{O}_{5} \cdot x \mathrm{H}_{2} \mathrm{O}$ would be the interfaces between the root regions of $\beta-\mathrm{Na}_{0.24} \mathrm{~V}_{2} \mathrm{O}_{5} \mathrm{NWs}$ and sodium metasilicate on the surface of substrate. The structure of $\beta-\mathrm{Na}_{0.24} \mathrm{~V}_{2} \mathrm{O}_{5}$ contains the 3D structure of $\mathrm{V}-\mathrm{O}$ network. The numbers of $\mathrm{V}-\mathrm{O}$ contacts on $b c$ plane are significantly larger than that of $\mathrm{V}-\mathrm{O}$ contacts along $a$-axis. Therefore, the preferred growth direction could be a direction on the $b c$ plane, and the TEM study indicates a growth direction perpendicular to the $a$-axis. The crystal growth might be affected by the stacking of $\mathrm{VO}_{x}$ and the nature of $\beta-\mathrm{Na}_{0.24} \mathrm{~V}_{2} \mathrm{O}_{5}$.

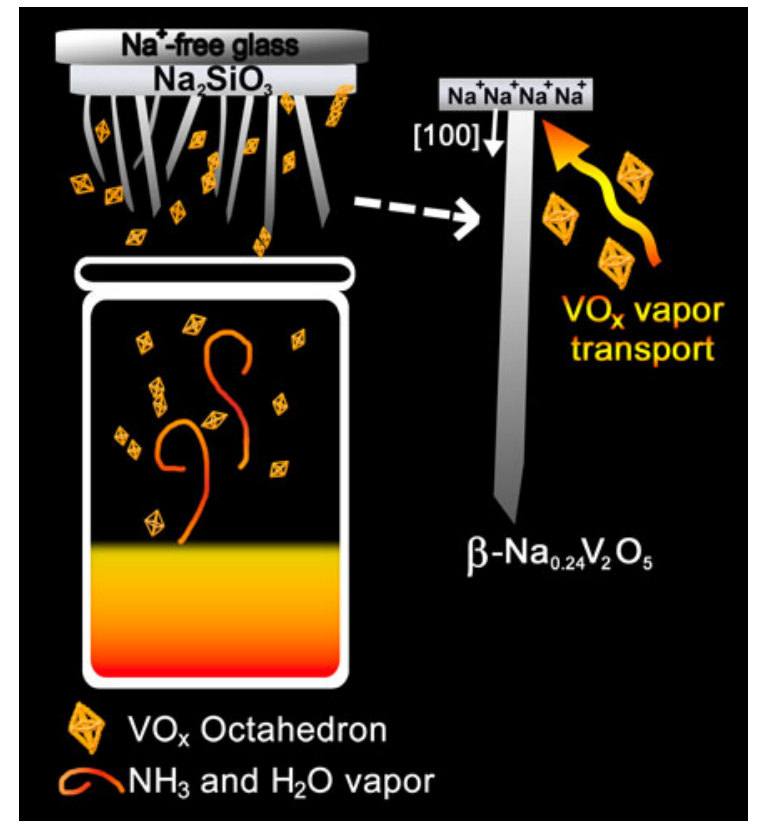

Scheme 1 Schematic illustration of reaction mechanism to deposit $\beta-\mathrm{Na}_{0.24} \mathrm{~V}_{2} \mathrm{O}_{5} \mathrm{NW}$ s on the surface of a substrate

Physical properties

To deduce the intrinsic optical properties of the $\beta-\mathrm{Na}_{0.24} \mathrm{~V}_{2} \mathrm{O}_{5} \mathrm{NWs}$ aligned on a glass substrate, we measured the optical absorption. Figure 8 shows the 


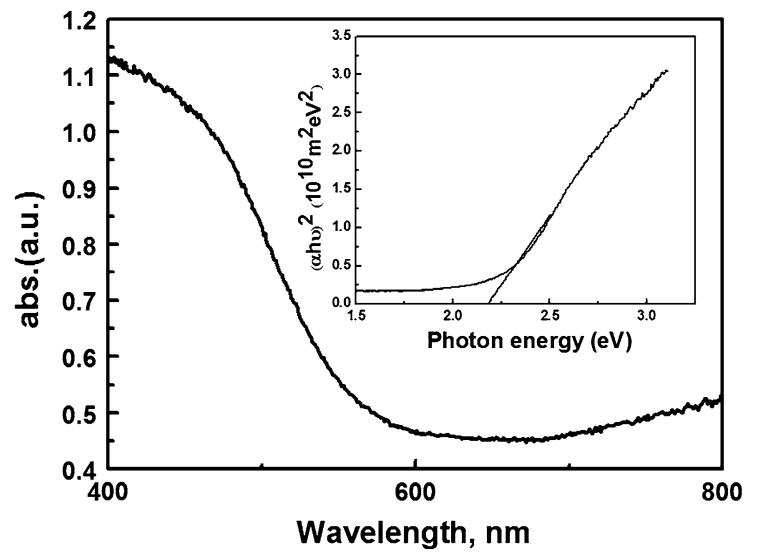

Fig. 8 UV-Visible absorption spectrum and a plot of $(\alpha h v)^{2}$ versus incident photon energy hv (inset) for the $\beta-\mathrm{Na}_{0.24} \mathrm{~V}_{2} \mathrm{O}_{5}$ thin film as prepared

UV-Visible absorption spectrum of $\beta-\mathrm{Na}_{0.24} \mathrm{~V}_{2} \mathrm{O}_{5}$ thin film, which exhibited an onset of absorption near $500 \mathrm{~nm}$. The optical band gap $\left(E_{\mathrm{g}}\right)$ for a typical product is calculated from the absorption coefficient, $\alpha$, according to the relation $\alpha h v=A\left(\mathrm{~h} v-E_{\mathrm{g}}\right)^{1 / 2}(A$ : constant, $h v$ : energy of incident photon) (Han et al. 2011; Saipriya et al. 2011). The inset of Fig. 8 shows the plot of $(\alpha h v)^{2}$ versus photon energy $h v$. The band gap of $2.18 \mathrm{eV}$ was obtained on extrapolating the linear part of the graph to $\alpha h v=0$, which was less than for $\mathrm{V}_{2} \mathrm{O}_{5} \mathrm{NW}, 2.48 \mathrm{eV}$ (Wu and Lee 2009b).

The films as prepared with nearly aligned $\beta-\mathrm{Na}_{0.24} \mathrm{~V}_{2} \mathrm{O}_{5}$ NWs exhibited an interesting field emission effect, which we measured with electrodes in a parallel-plate configuration and separation of $100 \mu \mathrm{m}$ between the anode and an emitting surface near $295 \mathrm{~K}$ of area $0.785 \mathrm{~mm}^{2}$. Figure 9 depicts the emission current density $(J)$ versus the applied macroscopic field $(E)$ for a bias voltage in a range $0-1,100 \mathrm{~V}$ between the anode and samples. The turnon field $\left(E_{\mathrm{to}}\right)$, defined as the macroscopic field required to produce a current density of $10 \mu \mathrm{A} / \mathrm{cm}^{2}$, was $\sim 7.8 \mathrm{~V} / \mu \mathrm{m}$. The FE current density attained $4.66 \mu \mathrm{A} /$ $\mathrm{cm}^{2}$ when the applied field increased to $11 \mathrm{~V} / \mu \mathrm{m}$. The FE properties between thin films of $\beta-\mathrm{Na}_{0.24} \mathrm{~V}_{2} \mathrm{O}_{5}$ and $\mathrm{V}_{2} \mathrm{O}_{5}$ NWs are summarized in Table 2. Our value of the turn-on field was less than that of the results reported for vanadium oxide $\mathrm{NWs}$ (Wu and Lee $2009 \mathrm{~b})$. The variation of the turn-on fields was attributed to the crystal structure and chemical composition. A Fowler-Nordheim $(\mathrm{F}-\mathrm{N})$ plot of $\left(\ln I / E^{2}\right)$ versus $(1 / E)$ appears in the inset of Fig. 9; a linear

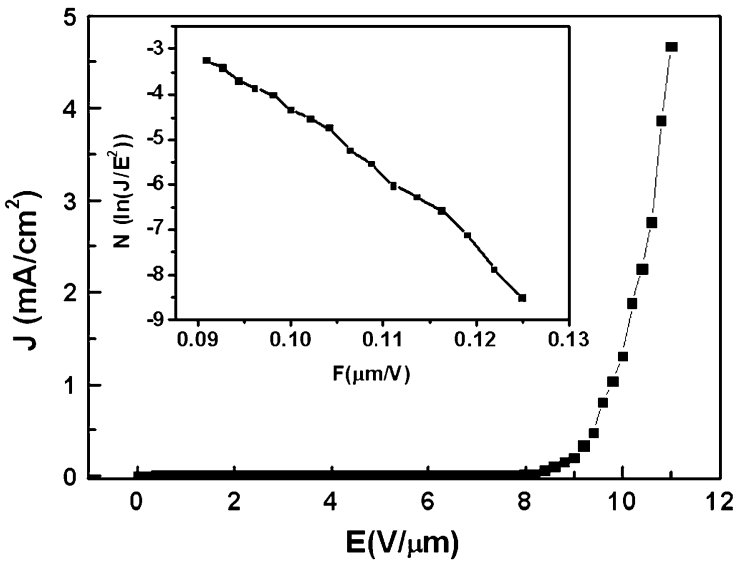

Fig. 9 Field-emission current density as a function of electric field applied to $\beta-\mathrm{Na}_{0.24} \mathrm{~V}_{2} \mathrm{O}_{5} \mathrm{NW}$ thin film as prepared. The inset shows its corresponding $\mathrm{F}-\mathrm{N}$ plot

Table 2 Comparison of FE properties between product as prepared and $\mathrm{V}_{2} \mathrm{O}_{5} \mathrm{NWs}$

\begin{tabular}{lll}
\hline & $E_{\text {to }}\left(\mathrm{V} \mathrm{\mu m}^{-1}\right)$ & $I_{\max }\left(\mathrm{mA} \mathrm{cm}^{-2}\right)$ \\
\hline $\mathrm{V}_{2} \mathrm{O}_{5} \mathrm{NW}$ & 8.3 & 1.8 at $18 \mathrm{~V} \mu \mathrm{m}$ \\
$\beta-\mathrm{Na}_{0.24} \mathrm{~V}_{2} \mathrm{O}_{5} \mathrm{NW}$ & 7.8 & 4.66 at $11 \mathrm{~V} \mu \mathrm{m}$ \\
\hline
\end{tabular}

relation indicated that the field emission from the film of $\beta-\mathrm{Na}_{0.24} \mathrm{~V}_{2} \mathrm{O}_{5} \mathrm{NWs}$ conformed to the $\mathrm{F}-\mathrm{N}$ theory, and that the emitted current was caused by quantum tunneling at the surface (Tang et al. 2005).

\section{Conclusion}

We fabricated nearly aligned single crystal form of $\beta-\mathrm{Na}_{0.24} \mathrm{~V}_{2} \mathrm{O}_{5} \mathrm{NWs}$ via a simple, economical, mild, and template-free method involving thermal evaporation. The diameter of the NWs, which grew along direction [ 1100 ], but tilted from the surface of the glass substrate, was $80-100 \mathrm{~nm}$; their average length was tens of micrometers. We have proposed a mechanism of crystal growth, and demonstrated that reaction temperature and precursor concentration were found to have a pronounced effect on distribution and length of $\beta-\mathrm{Na}_{0.24} \mathrm{~V}_{2} \mathrm{O}_{5} \mathrm{NWs}$. The NWs as obtained exhibited satisfactory properties of field emission with a turn-on field of $7.8 \mathrm{~V} / \mu \mathrm{m}$ and a maximum current density of $4.66 \mathrm{~mA} / \mathrm{cm}^{2}$ at an applied field of $11.0 \mathrm{~V} / \mu \mathrm{m}$ with a linear $\mathrm{F}-\mathrm{N}$ property, which might serve as a 
field-emission emitter. These results have provided a new strategy to synthesize ternary inorganic NWs with greater flexibility in controlling the size, shape, and coverage density of NWs on various substrates. This unique synthetic route is expected to be applicable to other aligned vanadium oxide bronze NWs, such as $\mathrm{M}_{x} \mathrm{~V}_{2} \mathrm{O}_{5}(\mathrm{M}=\mathrm{K}, \mathrm{Cu}, \mathrm{Ag})$.

Acknowledgments We thank Professor Hsin-Tien Chiu for FET measurements and Professor Teng-Ming Chen for UV measurements. The National Science Council (Contracts NSC98-2113-M-009-007-MY3, 98-3114-E-009-006, 99-3113P-009-005) and the MOE ATU program supported this research.

\section{References}

An JN, Xu CY, Zhen L, Huang YD (2010) Surfactant-free hydrothermal synthesis and characterization of singlecrystal $\mathrm{K}_{2} \mathrm{~V}_{8} \mathrm{O}_{21}$ nanobelts. Ceram Int 36(6):1825-1829

Ard S, Dibble CJ, Akin ST, Duncan MA (2011) Ligand-coated vanadium oxide clusters: capturing gas-phase magic numbers in solution. J Phys Chem C 115(14):6438-6447

Bakhteeva YA, Podval'naya NV, Volkov VL (2010) Gassensing properties of nanostructured $\mathrm{M}_{x} \mathrm{~V}_{2} \mathrm{O}_{5}(\mathrm{M}=\mathrm{Na}$, $\mathrm{K}, \mathrm{Rb}, \mathrm{Cs}$ ) oxides. Inorg Mater 46(10):1112-1114

Comini E, Baratto C, Faglia G, Ferroni M, Vomiero A, Sberveglieri G (2009) Quasi-one dimensional metal oxide semiconductors: preparation, characterization and application as chemical sensors. Prog Mater Sci 54(1):1-67

Dai Z, Pan Z, Wang Z (2003) Novel nanostructures of functional oxides synthesized by thermal evaporation. Adv Funct Mater 13(1):9-24

Dong F, Heinbuch S, Xie Y, Rocca JJ, Bernstein ER, Wang ZC, Deng K, He SG (2008) Experimental and theoretical study of the reactions between neutral vanadium oxide clusters and ethane, ethylene, and acetylene. J Am Chem Soc 130(6):1932-1943

Dong F, Heinbuch S, Xie Y, Rocca JJ, Bernstein ER (2009) Reactions of neutral vanadium oxide clusters with methanol. J Phys Chem A 113(13):3029-3040

Fan Z, Ho JC, Takahashi T, Yerushalmi R, Takei K, Ford AC, Chueh Y-L, Javey A (2009) Toward the development of printable nanowire electronics and sensors. Adv Mater 21(37):3730-3743

Galy J (1992) Vanadium pentoxide and vanadium oxide bronzes - structural chemistry of single (S) and double

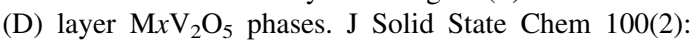
29-245

Grigorieva AV, Badalyan SM, Goodilin EA, Rumyantseva MN, Gaskov AM, Birkner A, Tretyakov YD (2010) Synthesis, structure, and sensor properties of vanadium pentoxide nanorods. Eur J Inorg Chem 33:5247-5253

Han J, Spanheimer C, Haindl G (2011) Optimized chemical bath deposited CdS layers for the improvement of CdTe solar cells. Sol Energy Mater Sol Cells 95(3):816-820

Isabelle R, Marko B, Ulrich S, Akio Y, Tobias V (2005) VO nanofibres: novel gas sensors with extremely high sensitivity and selectivity to amines. Sens Actuators B 106(2):730-735

Itoh M, Akimoto N, Yamada H, Isobe M, Ueda Y (2001) NMR study of local magnetic and electronic properties of vanadium bronzes. J Phys Chem Solids 62(1-2):351-354

Ji S, Zhao Y, Zhang F, Jin P (2010) Direct formation of single crystal $\mathrm{VO}_{2}(\mathrm{R})$ nanorods by one-step hydrothermal treatment. J Cryst Growth 312(2):282-286

Jiang Y, Zhang WJ, Jie JS, Meng XM, Zapien JA, Lee ST (2006) Homoepitaxial growth and lasing properties of $\mathrm{ZnS}$ nanowire and nanoribbon arrays. Adv Mater 18(12): $1527-1532$

Jiang J, Li Y, Liu J, Huang X (2011) Building one-dimensional oxide nanostructure arrays on conductive metal substrates for lithium-ion battery anodes. Nanoscale 3(1):45-58

Jiao L, Yuan H, Si Y, Wang Y (2006) Synthesis of $\mathrm{Cu}_{0.1}$-doped vanadium oxide nanotubes and their application as cathode materials for rechargeable magnesium batteries. Electrochem Commun 8(6):1041-1044

Khoo E, Wang J, Ma J, Lee PS (2010) Electrochemical energy storage in a $\beta-\mathrm{Na}_{0.33} \mathrm{~V}_{2} \mathrm{O}_{5}$ nanobelt network and its application for supercapacitors. J Mater Chem 20(38):8368

Kolasinski K (2006) Catalytic growth of nanowires: vaporliquid-solid, vapor-solid-solid, solution-liquid-solid and solid-liquid-solid growth. Curr Opin Solid State Mater Sci 10(3-4):182-191

Laugier J, Bochu B. CELREF, http://www.inpg.fr/LMGPS; Laboratoire des Materiaux et du Génie Physique de l'Ecole Supérieure de Physique de Grenoble

Li X, Chen X, Chen X, Han C, Shi C (2007) Hydrothermal synthesis and characterization of $\mathrm{VO}_{2}(\mathrm{~B})$ nanorods array. J Cryst Growth 309(1):43-47

Li L, Liu C, Liu Y (2009) Study on activities of vanadium (IV/V) doped $\mathrm{TiO}_{2}(\mathrm{R})$ nanorods induced by $\mathrm{UV}$ and visible light. Mater Chem Phys 113(2-3):551-557

Li XL, Cai KF, Li H, Yu DH, Wang X, Wang HF (2010) Alumina template-assisted electrodeposition of $\mathrm{Bi}_{2} \mathrm{Te}_{2.7} \mathrm{Se}_{0.3}$ nanowire arrays. Superlattices Microstruct 47(6):710-713

Liu JF, Wang X, Peng Q, Li YD (2005) Vanadium pentoxide nanobelts: highly selective and stable ethanol sensor materials. Adv Mater 17(6):764

Liu Y, Zhang Y, Zhang M, Qian Y (2006) A facile hydrothermal process of fabricating beta- $\mathrm{Ag}_{0.33} \mathrm{~V}_{2} \mathrm{O}_{5}$ single-crystal nanowires. J Cryst Growth 289(1):197-201

Liu A, Ichihara M, Honma I, Zhou H (2007) Vanadium-oxide nanotubes: synthesis and template-related electrochemical properties. Electrochem Commun 9(7):1766-1771

Liu J, Cao G, Yang Z, Wang D, Dubois D, Zhou X, Graff GL, Pederson LR, Zhang J-G (2008) Oriented nanostructures for energy conversion and storage. ChemSusChem 1(8-9): 676-697

Liu H, Wang Y, Li L, Wang K, Hosono E, Zhou H (2009) Facile synthesis of $\mathrm{NaV}_{6} \mathrm{O}_{15}$ nanorods and its electrochemical behavior as cathode material in rechargeable lithium batteries. J Mater Chem 19(42):7885

Nayak J, Sahu S, Kasuya J, Nozaki S (2008) CdS-ZnO composite nanorods: synthesis, characterization and application for photocatalytic degradation of 3,4-dihydroxy benzoic acid. Appl Surf Sci 254(22):7215-7218

Perlstein JH (1968) Single-crystal studies of electrical conductivity, seebeck effect, and hall voltage in sodium vanadium 
bronze and a crystal-field model of electron transport. J Chem Phys 48(1):174

Ramgir NS, Yang Y, Zacharias M (2010) Nanowire-based sensors. Small 6(16):1705-1722

Sahana MB, Shivashankar SA (2003) Growth of nanowires of $\beta-\mathrm{Nax}_{2} \mathrm{O} 5$ by metalorganic chemical vapor deposition. J Mater Chem 13(9):2254

Saipriya S, Sultan M, Singh R (2011) Effect of environment and heat treatment on the optical properties of RF-sputtered $\mathrm{SnO}_{2}$ thin films. Phys B 406(4):812-817

Sanmathi CS, Takahashi Y, Sawaki D, Klein Y, Retoux R, Terasaki I, Noudem JG (2010) Microstructure control on thermoelectric properties of $\mathrm{Ca}_{0.96} \mathrm{Sm}_{0.04} \mathrm{MnO}_{3}$ synthesised by co-precipitation technique. Mater Res Bull 45(5):558-563

Santangelo S, Messina G, Faggio G, Willinger M-G, Pinna N, Arena ADA, Donato N, Neri G (2010) Micro-Raman investigation of vanadium-oxide coated tubular carbon nanofibers for gas-sensing applications. Diam Relat Mater 19(5-6):590-594

Souza E, Lourenco A, Gorenstein A (2007) Structural, chemical and electrochemical analyses of $\mathrm{Cux} \mathrm{V}_{2} \mathrm{O}_{5}$ bronzes thin films. Solid State Ion 178(5-6):381-385

Tang Q, Li T, Chen X, Yu D, Qian Y (2005) Efficient field emission from well-oriented $\mathrm{CuO}$ film. Solid State Commun 134(3):229-231

Velazquez JM, Banerjee S (2009) Catalytic growth of singlecrystalline $\mathrm{V}(2) \mathrm{O}(5)$ nanowire arrays. Small 5(9): 1025-1029

Velazquez JM, Jaye C, Fischer DA, Banerjee S (2009) Near edge X-ray absorption fine structure spectroscopy studies of single-crystalline $\mathrm{V}_{2} \mathrm{O}_{5}$ nanowire arrays. J Phys Chem C 113(18):7639-7645

Wagner RS, Ellis WC (1964) Vapor-liquid-solid mechanism of single crystal growth. Appl Phys Lett 4(5):89

Wang ZL (2008) Oxide nanobelts and nanowires-growth, properties and applications. J Nanosci Nanotechnol 8(1): 27-55

Wang Y, Cao G (2006) $\mathrm{Li}^{+}$-intercalation electrochemical/ electrochromic properties of vanadium pentoxide films by sol electrophoretic deposition. Electrochim Acta 51(23): $4865-4872$

Wang Y, Cao G (2007) Synthesis and electrochemical properties of $\mathrm{InVO}_{4}$ nanotube arrays. J Mater Chem 17(9):894
Wang YQ, Zhang ZJ, Zhu Y, Li ZC, Vajtai R, Ci LJ, Ajayan PM (2008) Nanostructured $\mathrm{VO}_{2}$ photocatalysts for hydrogen production. ACS Nano 2(7):1492-1496

Wang K, Chen JJ, Zeng ZM, Tarr J, Zhou WL, Zhang Y, Yan YF, Jiang CS, Pern J, Mascarenhas A (2010) Synthesis and photovoltaic effect of vertically aligned $\mathrm{ZnO} / \mathrm{ZnS}$ core/ shell nanowire arrays. Appl Phys Lett 96(12):123105

Wei J, Natelson D (2011) Nanostructure studies of strongly correlated materials. Nanoscale 3(9):3509-3521

Wu MC, Lee CS (2009a) Alpha- $\mathrm{MoO}_{3}$ nanocrystals of controlled size on a glass substrate. Mater Res Bull 44(3): 629-632

Wu MC, Lee CS (2009b) Field emission of vertically aligned $\mathrm{V}_{2} \mathrm{O}_{5}$ nanowires on an ITO surface prepared with gaseous transport. J Solid State Chem 182(8):2285-2289

Xiong C, Aliev AE, Gnade B, Balkus KJ (2008) Fabrication of silver vanadium oxide and $\mathrm{V}_{2} \mathrm{O}_{5}$ nanowires for electrochromics. ACS Nano 2(2):293-301

Xu JJ, Zhang XT, Wang DJ, Du ZL, Li TJ (2005) A simple approach for the fabrication of $\mathrm{Na} 1+x \mathrm{~V}_{3} \mathrm{O}_{8}$ nanoribbon thin film. Chem Lett 34(6):838-839

Xu Y, Han X, Zheng L, Yan W, Xie Y (2011) Pillar effect on cyclability enhancement for aqueous lithium ion batteries: a new material of $\beta$-vanadium bronze $\mathrm{M}_{0.33} \mathrm{~V}_{2} \mathrm{O}_{5}$ $(\mathrm{M}=\mathrm{Ag}, \mathrm{Na})$ nanowires. J Mater Chem

Yamada H, Ueda Y (1999) Magnetic, electric and structural properties of beta- $\mathrm{A}(x) \mathrm{V}(2) \mathrm{O}(5)(\mathrm{A}=\mathrm{Na}, \mathrm{Ag})$. J Phys Soc Jpn 68(8):2735-2740

Yu J, Yu JC (2007) Large-scale in situ synthesis and characterization of ternary single-crystal $\mathrm{NaV}_{6} \mathrm{O}_{15}$ nanoneedles. Mater Chem Phys 104(2-3):362-366

Zhai T, Li L, Ma Y, Liao M, Wang X, Fang X, Yao J, Bando Y, Golberg D (2011) One-dimensional inorganic nanostructures: synthesis, field-emission and photodetection. Chem Soc Rev 40(5):2986-3004

Zhang K, Bao S, Liu X, Shi J, Su Z, Li H (2006) Hydrothermal synthesis of single-crystal $\mathrm{VO}_{2}(\mathrm{~B})$ nanobelts. Mater Res Bull 41(11):1985-1989

Zhou GT, Wang XC, Yu JC (2005) Selected-control synthesis of $\mathrm{NaV}_{6} \mathrm{O}_{15}$ and $\mathrm{Na}_{2} \mathrm{~V}_{6} \mathrm{O}_{16}$ center dot $3 \mathrm{H}(2) \mathrm{O}$ single-crystalline nanowires. Cryst Growth Des 5(3):969-974 